\title{
Development and Test of the Evaluation Scale of Foreign Trade Enterprises' Core Brand Competitiveness
}

\author{
Liu Jie \\ School of Marketing and Logistics Management \\ Nanjing University of Finance and Economics \\ Nanjing 210023, China \\ liujie6@126.com
}

\author{
Jin kang \\ School of Marketing and Logistics Management \\ Nanjing University of Finance and Economics \\ Nanjing 210023, China \\ mr_joyking@aliyun.com
}

\begin{abstract}
The development and transformation of China's foreign trade enterprises are facing many uncertainties for several years. It is necessary for the transformation and upgrading of China's foreign trade enterprises to improve the core brand competitiveness. How to measure the core brand competitiveness has been the focus of academic attention. On the basis of the literature analysis, we developed the evaluation index system of the core brand competitiveness of foreign trade enterprises by analytic hierarchy process, including the measure of consumer brand attitude, marketing ability, research and development ability, management ability, financing ability, production capacity and staff ability. This study had enriched the relevant research on the core brand competitiveness and provided practical guidance on how to improve the core brand competitiveness in foreign trade enterprises.
\end{abstract}

Keywords-foreign trade enterprise; core brand competitiveness; scale development; scale test

\section{INTRODUCTION}

Since 2018, the phenomenon of single-standard trade protectionism represented by the United States has become increasingly severe, and the development and transformation of China's foreign trade enterprises are facing many uncertainties. In the process of global economic integration, the Chinese economy has been affected by the impact of global economic adjustment. Besides, the appreciation of the RMB, the increasing cost of domestic production factors and the faster transfer of labor-intensive industries to Southeast Asian countries in recent years, which led to the grim development situation and the gradually weakened competitiveness in China's foreign trade industry. In 2016, China's total export value was US\$2,097.44 billion, down 7.7\% year-on-year; total imports were US\$1,587.48 billion, down 5.5\% year-on-year. Total import and export volume in 2017 increased by $11.4 \%$. Overall, the foreign trade environment has improved, but the fluctuations are too great.

With the intensification of competition in the foreign trade industry, the competition among enterprises shows a homogenization trend, it is necessary to find the right path and model to promote enterprise transformation and upgrading for the sustainable development of foreign trade industry. The brand has become an important symbol that guiding customers to identify products and helping enterprises differentiating their products from competitors. It is not only a kind of intangible asset that more important and more lasting than normal products, but also the core competitiveness of enterprises (Kevin Lane Keller, 2009)[1]. Combining brand theory with enterprise core competitiveness theory is the theoretical requirement in strategic development stage of brand, while combining brand management with traditional enterprise management is the practical requirement. Qiao Jun (2014)[2] argued that choosing the correct power to guide the development of enterprises was of great importance for enterprise upgrading. However, these enterprises were in fact taking two extremes directions, they either emphasized the objectivity of the production enterprises or insisted on building the development strategy based on the core competitiveness theory, or emphasized the role of subjective evaluation from consumer and adhered to the brand equity theory to build the development strategy. But only by combining the core competitiveness theory with the brand equity theory, could we better guide the transformation and upgrading of enterprises, and truly enhance the core competitiveness of enterprises in the international and domestic markets. For Chinese foreign trade enterprises, the current academic community got no unified understanding about what the elements of core brand competitiveness are, or how to measure it.

After combing and integrating the advice from domestic and foreign experts, we constructed an evaluation system of core brand competitiveness which was suitable for the present situation of foreign trade enterprises in China. We also provided foreign trade enterprises with theoretical guidance and reference in terms of evaluating and upgrading core competitiveness, thus this research not only shown a certain theoretical value and practical significance, but also met the requirements of brand management.

\section{THEORETICAL REVIEW}

\section{A. Core Brand Competitiveness}

Core brand competitiveness was a combination of the core competitiveness of enterprises and brand equity (Qiao Jun, 2014)[2], which was based on the traditional core competitiveness of enterprise. The core competitiveness of enterprise was first proposed by Prahalad on the Harvard Business Review in 1990. The core idea was that in a short time the greatest advantage of an enterprise was the quality 
and performance of the products it produced. However, from the long-term development point of view, the core competitiveness was the base for enterprise development, and technology and skills were suitable dimensions to assess the core competitiveness.

Brand equity was the measure of brand value; western scholars believed that brand equity theory could guide business practice to obtain the greatest brand competitive advantages and the correct measure of brand value. Such as Simon and Sullivan (1993)[3], they thought the brand assets determined the value of the enterprise or corporate brand and for provided the strategic evaluation of information for enterprise, brand equity was the key to explore the core brand competitiveness and brand evaluation. It was verified by Keller(1993)[4] that brand could positively affect customer value and lead to customer loyalty, from this point of view, brand equity was the basis of core competitiveness. Kotler(2001)[5] thought the brand was an "intangible contract" between the enterprise and the consumer. The enterprise raised the consumer perception on the product service, the quality and the value through the commercial commitments, the consumer would pay the "brand premium" to the enterprise in the satisfaction, and such a "reciprocal market exchange relationship "based on" invisible contract gradually formed a core brand competitiveness of enterprises. In summary, the core brand competitiveness was formed in a certain market environment, it was conducive for enterprises to shape a strong brand and supported the sustainable development of the brand, and shown a depth of dependence on consumer brand attitude.

We mainly focused on the research and academic perspectives about core brand competitiveness from China's studies, as foreign scholars had insufficient research in this field. Xu Jinan(2005)[6] regarded the core brand competitiveness as an ability integrated by other elements, it could be divided into three dimensions, namely the market performance, management capacity and brand base. Qiao Jun (2013) [7] proposed that the core brand competitiveness come from two aspects: the core competitiveness of enterprises and the impact of the brand on the consumer. So far, there was no unified definition of the core brand competitiveness in the academic circles. We held that the connotation of the core brand competitiveness could be described as "brand + core competitiveness", namely taking into account the brand association of the consumers on the basis of core enterprise competitiveness, which meant that external brand image and intrinsic quality, technical performance, service, of an enterprise could continue to distinguish or ahead of other competitors, with a competitive advantage and the ability to provide value for profit.

\section{B. Evaluation of Core Brand Competitiveness}

Scholars mainly conducted their research from the aspect of consumer, business, industry, etc.. Xu Jinan (2005)[6] divided the definition of core brand competitiveness into three levels: the market performance, management capacity and brand base, based on which he built the core brand competitiveness evaluation system from three dimensions, namely the brand market ability, brand management capabilities and basic brand ability. Bai Yu (2005[8] added "brand relationship ability" into the core brand competitiveness evaluation index system promoted by Xu Jinan (2005)[6] then the system was expanded to four levels, including brand market ability, brand management ability, brand relationship ability and brand base ability. Qiao Jun (2013)[7] systematically defined the six elements of core brand competitiveness, including manufacturing capacity, marketing ability, R\&D capabilities, management capabilities, staff capacity and consumer brand attitude, then he developed the evaluation index system for local manufacturing industry, namely BCCI (Core brand Competency Index) model. (Shown as Table I)

TABLE I. SUMMARY OF THE EVALUATION INDEX SYST EM OF CORE BRAND COMPETITIVENESS

\begin{tabular}{|c|c|c|}
\hline Year & Scholar & Evaluation index system \\
\hline 1996 & Zhang Shixian & Market share, super profit margin \\
\hline 2005 & Xu jinan[6] & $\begin{array}{l}\text { Brand market ability: brand market share, brand profitability, brand sustainable development capacity; } \\
\text { Brand management ability: brand positioning ability, brand communication ability, brand operation ability; } \\
\text { Basic brand ability: enterprise management ability, technological innovation ability, human capital and entrepreneur, corporate culture }\end{array}$ \\
\hline 2005 & Liu ingqiu & M arketing and market development, technological R\&D and innovation, production organization and management \\
\hline 2005 & Bai Yu[8] & $\begin{array}{l}\text { Brand market ability: brand market share, brand profitability, brand sustainable develop ment capacity; } \\
\text { Brand management capabilities: brand p ositioning, brand communication, brand operation; } \\
\text { Brand relationship: brand and cust omer, brand and supplier, brand and related partners; } \\
\text { Basic brand ability: management ability, technological innovation ability, human cap ital entrepreneur, corporate culture }\end{array}$ \\
\hline 2005 & Shen Zhanbo & $\begin{array}{l}\text { Externality index: brand market power index, brand image force index, brand financial force index; } \\
\text { Potential index: brand quality support, brand innovation and brand resources supporting }\end{array}$ \\
\hline 2008 & Han Furong & $\begin{array}{l}\text { Brand awareness: workinglife, image level, development trend, cognitive state; } \\
\text { Brand well-known: well-known state, source, communication, dissemination evaluation, sales imp act, identification system, promotion category; } \\
\text { Brand reputation: credibility to catch, the credibility of competition, industry reputation, customer choice, commitment to quality, reputation channels; } \\
\text { Brand loy alty: customer group, difference value, commitment to cash, communication, source status, distribution area; } \\
\text { Brand association: association state, connotationstate, group status, connotation mining }\end{array}$ \\
\hline 2009 & Huang Shengquan & $\begin{array}{l}\text { Brand market ability: market share, market penetration, market responsiveness; } \\
\text { Brand creation capacity: sales growthcap acity, profit growth capacity; } \\
\text { Brand development ability: brand awareness, brand reputation, brand loy alty }\end{array}$ \\
\hline 2013 & Qiao Jun[7] & $\begin{array}{l}\text { Manufacturing cap acity: annual revenue, advanced production equipment, the number of production lines; } \\
\text { R\&D cap acity: the number of researchers, R\&D expenses, proprietary technology and the number of patents; } \\
\text { Marketing ability: the proportion of marketing staff, sales accounted for the prop ortion of sales revenue, sales revenue accounted for the prop ortion of } \\
\text { total output value; } \\
\text { Enterprise staff cap acity: the education degree, education funding, The ratio of total output to the number of employees; } \\
\text { Management ability: the education degree of executives, the average profit growth rate, management consulting costs, earnings per share, stock market } \\
\text { value; } \\
\text { Consumer brand attitude: brand awareness, brand loy alty, brand satisfaction, brand association, perceivedbrand quality }\end{array}$ \\
\hline
\end{tabular}


We found that there were few research results we could refer to, so we took the research of the core competitiveness of foreign trade enterprises as a theoretical reference to construct the evaluation system of the core competitiveness of foreign trade enterprises in China. By using diamond model, Yao Xiaoxiao (2015)[9] analyzed and summarized four factors that impact the core competitiveness of China's foreign trade enterprises, including production, demand conditions, related industries and industry supporting, corporate strategy and rivals. Li Hongyu (2016)[10] summarized the influencing factors of the core competitiveness of China's small and medium-sized foreign trade enterprises from the direct and indirect perspective, the direct factors including business projects, business conditions, government policies and brand building ; while the indirect factors, including industry conditions, industry standards and other environmental issues, and even China's economic situation may have influences on the core competitiveness of such enterprises. Wang Xiaodan(2016)[11] divided the evaluation index system into five levels, including company size, financing capacity, profitability R\&D capacity and management ability. She conducted quantitative evaluation on the core competitiveness of China's small and medium-sized foreign trade enterprises through principal component analysis method, the result of which showed that China's small and medium-sized foreign trade enterprises should focus their efforts on innovation, financing, brand, management and other aspects to enhance their core competitiveness. The above-mentioned scholars on the core competitiveness of China's foreign trade enterprises provided one of the theoretical bases of designing core brand competitiveness evaluation dimensions of foreign trade enterprises.

The evaluation system or the evaluation perspective of the core brand competitiveness of the enterprises is not yet unified, but studies are mainly focused on the production, knowledge, management, marketing, human and other aspects, these aspects not only contain key elements of the core enterprise competitiveness but also consider into the brand associative factors. We would make full use of and summarize the above research results, on the basis of which we developed core brand competitiveness scale of foreign trade enterprise and did test of adaptability and scientificity.

\section{EVAluation Scale}

The classic path of scale developing proposed by Likert included three parts of survey design, questionnaire development and data analysis, later studies on the scale. Based on previous research, we further divided the development of core brand competitiveness evaluation scale into four sub-steps, respectively are design, revision, empowerment and analysis. Among them, the revision and empowerment of scale need to fully integrate expert investigation method, we revised indicators based on the list of established indicators through the expert survey method, and we got the weight of the index on the basis of the final index system through expert scoring, and ultimately developed a complete scale system.

\section{A. Scale Developing}

Through combing the research outcomes on the corporate core brand competitiveness evaluation index system we mentioned above, we could sum up two main sources affected the core brand competitiveness: core enterprise competitiveness and the impact of the brand on the consumer. We mainly referred to BCCI model (Qiao Jun, 2013)[7], combined with production mode, operation mode and other characteristics of foreign trade enterprises, to develop the construction scale. BCCI model consists of manufacturing capacity, marketing ability, management ability, research and development ability, staff ability and consumer brand attitude six dimensions and 21 sub-indicators. According to the BCCI model (Qiao Jun, 2013)[7], the selected evaluation dimension of local manufacturing enterprises' core brand competitiveness are manufacturing capacity, marketing ability, management ability, research and development ability, staff ability and consumer brand attitude. Taking into account the characteristics of foreign trade enterprises, we replaced the "production capacity" in the BCCI model by "production capacity"(Yao XiaoXiao, 2015)[9], add "enterprise scale" and "financing capacity" (Wang Xiaodan,2016)[11] into the new model, and retained the rest dimensions of BCCI model. In summary, we divided the evaluation system of foreign trade enterprises' core brand competitiveness into eight dimensions, namely, production capacity, firm size, financing ability, marketing ability, management ability, R\&D ability, staff ability and consumer brand attitude. The connotation of each dimension was explained in Table II.

TABLE II. EXPLANATIONS OF SECONDARY DIMENSIONS

\begin{tabular}{c|l}
\hline Dimension & Connotation \\
\hline Production capacity & A technicalparameter that reflects the processing capacity of the firm \\
\hline Enterprise scale & The scale effect of enterprises on tangible and intangible assets \\
\hline Financing capacity & The level of funding that an enterprise may finance is the ability to continue to acquire long-term high-quality capital \\
\hline Marketing ability & The distribution of the terminal and the sales channel, and the market share of the product or service \\
\hline Management ability & Organization and management skills, leadership and so on \\
\hline R\&D capabilities & The ability of enterprises to introduce talents, product or service innovation \\
\hline Staff capacity & Employee employees have the skills and ability to work
\end{tabular}

Based on the literature combed above we initially develop brand competitiveness, as shown in Table III.

the evaluation indicator list of foreign trade enterprises' core 
TABLE III. EVALUATION INDICATOR LIST OF FOREIGN TRADE ENTERPRISES’ CORE BRAND COMPETITIVENESS

\begin{tabular}{|c|c|c|}
\hline Target layer & Criteria layer & Index layer \\
\hline \multirow{8}{*}{ Core brand competitiveness } & Production capacity & $\begin{array}{l}\text { Total revenue; } \\
\text { Operating income; } \\
\text { Net profit; }\end{array}$ \\
\hline & Enterprise scale & $\begin{array}{l}\text { Main business income; } \\
\text { Total assets; } \\
\text { Total market value; } \\
\text { number of employees; }\end{array}$ \\
\hline & Financing capacity & $\begin{array}{l}\text { Total financing; } \\
\text { Accounts receivable turnover; } \\
\text { Long term loan; } \\
\text { Fixed assets; }\end{array}$ \\
\hline & Marketing ability & $\begin{array}{l}\text { The number of marketing staff accounted for the proportion of the number } \\
\text { of employees; } \\
\text { The proportion of sales expenses to sales revenue; } \\
\text { The proportion of sales revenue to total income; } \\
\text { Advertising spending; }\end{array}$ \\
\hline & Management ability & $\begin{array}{l}\text { The status of the manager; } \\
\text { The number of managers accounted for the proportion of the number of employees; } \\
\text { Management costs; } \\
\text { Earnings per share }\end{array}$ \\
\hline & R \& D capabilities & $\begin{array}{l}\text { Number of R \& D personnel; } \\
\text { Research and development expenses; } \\
\text { New product / technology development cycle; } \\
\text { Number of patents }\end{array}$ \\
\hline & Staff capacity & $\begin{array}{l}\text { Staff education level; } \\
\text { Trade union funds and staff education funding; } \\
\text { Total revenue and the proportion of the number of employees; } \\
\text { Employee benefits }\end{array}$ \\
\hline & Consumer brand attitude & $\begin{array}{l}\text { Brand awareness; } \\
\text { Brand satisfaction; } \\
\text { Brand loyalty; } \\
\text { Brand association degree; } \\
\text { Brand perceived service quality }\end{array}$ \\
\hline
\end{tabular}

The indicator list in table3 could be divided into three levels: the first level was the target layer. The second level was the criterion layer, including the production capacity, the scale of the enterprise, the financing ability, the marketing ability, the management ability, R\&D capabilities, staff capacity and consumer brand attitude; the third level was the index layer contained a total of 32 indicators. We then further amended and improved the list of indicators by expert questionnaire. The experts who gave weight to each indicator were generally not less than 3 in analytic hierarchy process, and 10 was the optimal number (Jiang Wenneng, 2013)[12] . Thus, we collected advice and have received effective feedback from 10 experts majored in marketing and management, business administration, and enterprise management; they come from various colleges and universities in Nanjing, Jiangsu Province.

\section{B. Scale Testing}

After summarizing the feedback of expert questionnaires, the proposed amendments were as follows: removed the "enterprise scale" indicators in the criteria layer, because the secondary indicators of which coincided with the indicators of production capacity and "scale" was not necessarily related to brand competitiveness. In the indicator layer, the "operating income" was removed by "main business income", "total income" and "net profit" were deleted because they might be repeatedly expressed, and the "earnings per share" indicator subordinated the "management ability" dimension was transferred to "production capability" dimension; the four indicators subordinated to "enterprise scale" were all deleted. "Long-term borrowing" was replaced by 'the proportion of long-term borrowing to total liabilities" in order to highlight its importance, similarly, the "advertising spending" was replaced by "advertising expenditure accounted for the proportion of sales revenue", "management fees" to "management costs accounted for the proportion of sales revenue", "R\&D staff" to "R\&D staff Number of R\&D staff accounted for the number of employees", "R\&D expenses" to " R\&D costs and their share of sales revenue", "trade union funds and staff education funds" to "staff education expenditure accounted for the proportion of sales revenue"; Besides, in order to maintain the normative performance of the evaluation index, we replaced "manager's education status" by "the manager's education level", and took into account the availability of the data we delete "new product / technology development cycle" and "number of patents", took into account the accuracy and necessity of the evaluation of indicators we delete " fixed assets "," the proportion of total income to the number of employees "and" employee benefits ". In addition, some experts suggested that the core brand competitiveness elements should consider into the 'brand quality management capabilities", because the essence of the brand content was the product. Product quality ensured the brand to enter the market successfully, so the core brand competitiveness was mainly embodied in the characteristics, performance and advantages of the products or services, such as the product characteristics, price, quality, service and delivery concerned by customers. Unfortunately, taking into account the availability of data and the ease of quantification calculations, the concept of "brand quality management capability" was discarded. Finally, we 
reduced the number of indicators to 21 , and the index system is shown in Table IV. Among them, the five indicators under the "consumer brand attitude" dimension are subjective indicators, and the remaining 16 indicators are objective indicators.

TABLE IV. EVALUATION INDEX SYSTEM OF FOREIGN TRADE ENTERPRISES' CORE BRAND COMPETITIVENESS

\begin{tabular}{|c|c|c|}
\hline Target layer & Criteria layer & Index layer \\
\hline \multirow{7}{*}{$\begin{array}{c}\text { Core brand } \\
\text { competitiveness U }\end{array}$} & Production capacity B1 & $\begin{array}{l}\text { Main operating income C1 } \\
\text { Earnings per share C2 }\end{array}$ \\
\hline & Financing capacity B2 & $\begin{array}{l}\text { Total financing C3 } \\
\text { Accounts receivable turnover C4 } \\
\text { Long-term borrowings as a percentage of total liabilities C5 }\end{array}$ \\
\hline & Marketing ability B3 & $\begin{array}{l}\text { The number of marketing staff accounted for the proportion of the number of employees C6 } \\
\text { The proportion of sales expenses to sales revenue C7 } \\
\text { The proportion of sales revenue to total income C8 } \\
\text { The proportion of advertising expenditure to sales revenue C9 }\end{array}$ \\
\hline & Management ability B4 & $\begin{array}{l}\text { Manager's degree of education C10 } \\
\text { The number of managers accounted for the proportion of the number of employees C11 } \\
\text { administrative expenses accounted for sales revenue C12 }\end{array}$ \\
\hline & R \& D capabilities B5 & $\begin{array}{l}\text { Number of R \& D staff accounts for the number of employees C13 } \\
\text { R \& D expenses accounted for the proportion of sales revenue C14 }\end{array}$ \\
\hline & Staff capacity B6 & $\begin{array}{l}\text { Staff education level C15 } \\
\text { Trade union funds and staff education expenses accounted for the proportion of sales revenue }\end{array}$ \\
\hline & $\begin{array}{l}\text { Consumer brand } \\
\text { attitude B7 }\end{array}$ & $\begin{array}{l}\text { Brand awareness C17 } \\
\text { Brand satisfaction C18 } \\
\text { Brand loyalty C19 } \\
\text { Brand association degree C20 } \\
\text { Brand perceived service quality C21 }\end{array}$ \\
\hline
\end{tabular}

The explanations of the 16 objective indicators are as follows: (1) Main operating income and (2) Earnings per share are financial indicators that can be obtained directly from the annual report of the enterprise, they reflect the production efficiency of the enterprise; (3) Total financing are measured by the amount of cash flow generated, reflecting the enterprise's financing capacity and project attraction; (4) accounts receivable turnover $=$ sales revenue $/$ annual average accounts receivable, reflecting the company's turnover rate of accounts receivable rate; (5) Percentage of long-term borrowings to total liabilities = long-term borrowing $/$ total liabilities, reflecting the quality of financing; (6) The number of marketing staff accounted for the proportion of the number of employees = number of marketing employees / number of employees, reflecting the company's human resources investment in marketing business; (7) The proportion of sales expenses to sales revenue $=$ sales expenses $/$ sales revenue, reflecting the company's financial investment in the marketing business. (8) The proportion of sales revenue to total income = sales revenue / gross income, reflecting the company's marketing business performance; (9) The proportion of advertising expenditure to sales revenue = advertising expenditure / sales revenue, reflecting the company's financial efforts in marketing; (10) Manager's degree of education = number of managers / number of staff with bachelor and higher education degree , reflecting the quality of managers; (11) Number of managers accounted for the number of employees $=$ number of managers / number of employees, reflecting the construction of company's management team; (12) administrative expenses accounted for sales revenue = administrative expenses / sales revenues, reflecting the company's financial investment in management work; (13) number of R\&D staff accounted for the proportion of the number of employees $=$ number of $R \& D$ personnel $/$ number of employees, reflecting the construction of technological and R\&D team; (14) R\&D expenses accounted for sales revenue = R \& D expenses / sales, reflecting the company's financial investment in research and development; (15) Staff education level $=$ number of employees / number of employees with bachelor and higher education degree, reflecting the company's overall quality situation of the staff; (16) Trade union funds and staff education expenses accounted for the proportion of sales revenue $=$ union funds and employee education expenses / sales, reflecting the company's financial investment in education and training and quality development.

As shown in Table V, we further explained the indicators in "consumer brand attitude" dimension. 
TABLE V. CONSUMER BRAND ATTITUDE INDICATORS

\begin{tabular}{|c|c|c|}
\hline Level 1 indicators & Secondary indicators & $\begin{array}{c}\text { Level } 3 \text { indicators } \\
\end{array}$ \\
\hline \multirow{13}{*}{$\begin{array}{l}\text { Foreign trade enterprises consumer } \\
\text { brand attitude }\end{array}$} & \multirow{2}{*}{ Brand awareness C17 } & Consumers of foreign trade enterprises know the degree of brand \\
\hline & & Consumers believe that the brand products/ services and other brands of distinction \\
\hline & \multirow{2}{*}{ Brand satisfaction C18 } & Consumers' satisfaction with the brand's product / service quality \\
\hline & & Consumer satisfaction with the branded product/service price \\
\hline & \multirow{2}{*}{ Brand loyalty C19 } & Consumers take the initiative to choose the brand product / service possibilities \\
\hline & & The brand products / services will still choose the possibility of price increases \\
\hline & \multirow{2}{*}{$\begin{array}{l}\text { Brand association degree } \\
\text { C20 }\end{array}$} & Consumers of the brand of the company's appreciation of the situation \\
\hline & & The trust of the consumer of the brand \\
\hline & \multirow{5}{*}{$\begin{array}{l}\text { Brand perceived service } \\
\text { quality } \\
\text { C21 }\end{array}$} & $\begin{array}{ll}\text { Reliability C211 } & \text { Provide the timeliness of the committed services } \\
\end{array}$ \\
\hline & & $\begin{array}{l}\text { To provide services to consumers to meet the needs of customers } \\
\text { in a timely manner }\end{array}$ \\
\hline & & In contact with employees, consumers feel safe and at ease \\
\hline & & $\begin{array}{l}\text { From the consumer demand to provide personalized service } \\
\text { attention }\end{array}$ \\
\hline & & Attractiveness of corporate tangible image \\
\hline
\end{tabular}

The weight of the index should be determined before we conducted the comprehensive evaluation, the higher the importance of the index, the greater the weight of the index. Normally we used AHP (Analytic Hierarchy Process) method to determine the weight. After determining the target layer, the criterion layer and the code index layer of the empirical brand research, the weight coefficient of the relative importance order of all the elements was determined by mathematical method.

Establish a set of assessment indicators. The evaluation index set was divided into three layers: the target layer $U$, the criterion layer B and the index layer $\mathrm{C}$. The specific structure was:

$$
\mathrm{U}(\mathrm{B})=\{\mathrm{B} 1, \mathrm{~B} 2, \mathrm{~B} 3, \mathrm{~B} 4, \mathrm{~B} 5, \mathrm{~B} 6, \mathrm{~B} 7\} ; \mathrm{C}(\mathrm{B} 1)=
$$

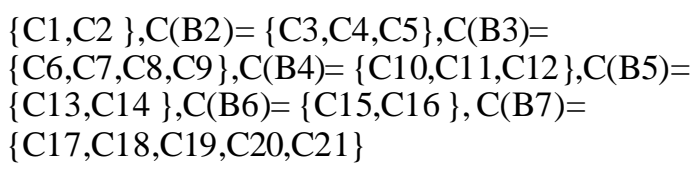

Construct the judgment matrix. We constructed the judgment matrix according to $\mathrm{U}=\left[\mathrm{U}_{\mathrm{ij}}\right] \mathrm{n}^{*} \mathrm{n}, \mathrm{U}_{\mathrm{ij}}$ represented the importance of $\mathrm{Bi}$ relative to $\mathrm{B}_{\mathrm{j}}$, and was represented by numerical values. In this paper, we interviewed experts from 10 universities in Nanjing, such as marketing management, business administration and business management, and each expert gave the value of relative importance (with level from 1-9), then we imported the data into Yaahp to calculate the weight of the indicators, as shown in Table VI.

TABLE VI. INDEX WEIGHT OF THE EVALUATION SYSTEM OF FOREIGN TRADE ENTERPRISES’ CORE BRAND COMPETITIVENESS

\begin{tabular}{|c|c|c|c|c|}
\hline Target layer & Criteria layer & $\begin{array}{l}\text { Criteria layer } \\
\text { weight }\end{array}$ & Index layer & $\begin{array}{c}\text { Index layer } \\
\text { weight }\end{array}$ \\
\hline \multirow{21}{*}{$\begin{array}{l}\text { Core brand } \\
\text { competitiveness } U\end{array}$} & \multirow{2}{*}{$\begin{array}{l}\text { Production capacity } \\
\text { B1 }\end{array}$} & \multirow{2}{*}{0.0541} & Main operating income C1 & 0.0406 \\
\hline & & & Earnings per share C2 & 0.0135 \\
\hline & \multirow{3}{*}{ Financing capacity B2 } & \multirow{3}{*}{0.0923} & Total financing C3 & 0.0567 \\
\hline & & & Accounts receivable turnoverC4 & 0.0248 \\
\hline & & & Long-term borrowings as a percentage of total liabilities C5 & 0.0108 \\
\hline & \multirow{4}{*}{ Marketing ability B3 } & \multirow{4}{*}{0.2038} & $\begin{array}{l}\text { The number of marketing staff accounted for the proportion of the } \\
\text { number of employees C6 }\end{array}$ & 0.0335 \\
\hline & & & The proportion of sales expenses to sales revenue C7 & 0.0214 \\
\hline & & & The proportion of sales revenue to total income C8 & 0.0580 \\
\hline & & & The proportion of advertising expenditure to sales revenue C9 & 0.0908 \\
\hline & \multirow{3}{*}{$\begin{array}{l}\text { Management ability } \\
\text { B4 }\end{array}$} & \multirow{3}{*}{0.1294} & The degree of education of the manager C10 & 0.0795 \\
\hline & & & $\begin{array}{l}\text { The number of managers accounted for the proportion of the number } \\
\text { of employees C11 }\end{array}$ & 0.0347 \\
\hline & & & The proportion of management expenses to sales revenue C12 & 0.0152 \\
\hline & \multirow[b]{2}{*}{ R \& D capabilities B5 } & \multirow[b]{2}{*}{0.1371} & Number of R \& D staff accounts for the number of employees C13 & 0.0457 \\
\hline & & & $\begin{array}{l}\text { Research and development expenses accounted for the proportion of } \\
\text { sales revenue C14 }\end{array}$ & 0.0914 \\
\hline & \multirow[b]{2}{*}{ Staff capacity B6 } & \multirow[b]{2}{*}{0.0364} & Staff education level C15 & 0.0273 \\
\hline & & & $\begin{array}{l}\text { Trade union funds and staff education expenses accounted for the } \\
\text { proportion of sales revenue C16 }\end{array}$ & 0.0091 \\
\hline & \multirow{5}{*}{$\begin{array}{l}\text { Consumer brand } \\
\text { attitude B7 }\end{array}$} & \multirow{5}{*}{0.3468} & Brand awareness C17 & 0.0171 \\
\hline & & & Brand satisfaction C18 & 0.0420 \\
\hline & & & Brand loyalty C19 & 0.1413 \\
\hline & & & Brand association degree C20 & 0.0587 \\
\hline & & & Perceived brand service quality C21 & 0.0878 \\
\hline
\end{tabular}

In particular, for the indicators under perceived brand service quality C21, we need to further determine its index weight by judgment matrix(C21-C21i). C21=

$\{\mathrm{C} 211, \mathrm{C} 212, \mathrm{C} 213, \mathrm{C} 214, \mathrm{C} 215\}$. The results were shown in 
Table VII

TABLE VII. SUB-INDEX WEIGHT OF PERCEIVED BRAND SERVICE QUALITY

\begin{tabular}{lll}
\hline \multirow{3}{*}{$\begin{array}{l}\text { Brand perceived } \\
\text { service quality }\end{array}$} & Reliability C211 & 0.1644 \\
\cline { 2 - 3 } C21 & Responsiveness C212 & 0.0735 \\
\cline { 2 - 3 } & Guaranteed C213 & 0.2370 \\
\cline { 2 - 3 } & Empathy C214 & 0.0281 \\
\cline { 2 - 3 } & Tangible C215 & 0.4969 \\
\hline
\end{tabular}

The consistency test showed that the decision matrix consistency ratio $\mathrm{CR}=0.0164<0.1$, the criterion layer's consistency matrix CR respectively were $0.0000,0.0707$, 0.0967, 0.0707, 0.0000, 0.0000 and 0.0220, and the judgment matrix CR of perceived brand service quality was 0.0871 . All of the CR were less than 0.1 , indicated the judgment matrix could be regarded as a consistency check. The criteria layer weight was:

W0

$=(0.0541,0.0923,0.2038,0.1294,0.1371,0.0364,0.3468)$,

Weights of each criteria layer were:

$\mathrm{W} 1=(0.0406,0.0135)$,

$\mathrm{W} 2=(0.0567,0.0248,0.0108)$,

$\mathrm{W} 3=(0.0335,0.0214,0.0580,0.0908)$,

$\mathrm{W} 4=(0.0795,0.0347,0.0152)$,

$\mathrm{W} 5=(0.0457,0.0914)$,

W6 $=(0.0273,0.0091)$,

$\mathrm{W} 7=(0.0171,0.0420,0.1413,0.0587,0.0878)$

Particularly, the Sub-index weight of perceived brand service quality was:

W75 $=(0.1644,0.0735,0.2370,0.0281,0.4969)$

\section{Analysis of the Evaluation Scale}

In this paper, we constructed an evaluation system of core brand competitiveness which included seven criterion layer dimensions and 21 indicators of the index layer. (1) In the criterion layer, the expert weight of the "consumer brand attitude" index was the highest, and this result was consistent with that of Qiao Jun (2013[7]), reflecting the important influence of the consumer to the subjective evaluation of product and service brand. Followed by which were the marketing ability, R \& D capabilities, management capacity, financing capacity, production capacity, and staff capacity which was the lowest one. (2) The weight of the marketing ability was relatively high, reflecting that the enterprise's layout of the terminal network and the management of marketing channels was strong in the foreign trade industry, and the market share of end product and service had a high influence on the entire enterprises' core brand competitiveness (3) The weight of R \& D capability equaled to that of management expertise, these two dimensions were of middle importance in the core brand competitiveness evaluation system , the weight of R \& D capability was a little higher than the management capacity, reflecting that in the era of high brand competition, the impact of products and services innovation to the brand had beyond that of the traditional enterprise management and brand management, thus enterprises need to increase $\mathrm{R} \& \mathrm{D}$ investment and improve innovation; (4) The evaluation significance of the three dimensions of financing ability, production capacity and staff ability was roughly the same as that of traditional core enterprise competitiveness evaluation system. It was worth noting that in the rapid development of Internet finance, the financing ability of enterprises need to advancing with the times. Relying on the development of the internet financial to improve the efficiency of financing and capital operation, which could also drive the promotion of production capacity and staff capacity, and further enhance the core brand competitiveness.

\section{DISCUSSION}

Based on the previous research on core brand competitiveness, especially studies on the evaluation system of foreign trade enterprises' core brand competitiveness, we studied the measurement and evaluation of the core brand competitiveness of foreign trade enterprises by gathering expert opinion, and has then developed an evaluation scale that includes 7 secondary dimensions and a total of 21 level 3 indicators. The scale was tested from both the expert and the consumer perspective. Consumer brand attitude dimension got the highest weight in 7 dimensions, which reflected the importance of consumer perception and association in the core brand competitiveness evaluation system. This research has enriched the research results of the core competencies of foreign trade enterprises in the field of foreign trade enterprises. In particular, the core competitiveness scale of foreign trade enterprises has important reference value for the comprehensive quantitative analysis of core competencies of foreign trade enterprises. Besides, we also provide practical indications for the enterprises to enhance the core brand competitiveness from the perspective of enterprise management. Future studies can do more empirical research on the local enterprises on the basis of this evaluation system and make a correction of the index weight according to the actual situation of the enterprises. Future studies can also carry out longitudinal research in time series; endeavor to enhance the core brand competitiveness of enterprises.

\section{REFERENCES}

[1] Kevin Lane Keller. Strategic Brand Management [M]. Beijing: Renmin University of China Press, 2009.

[2] Qiao Jun. Study on Improving the Core Competitiveness of Local Brands - Based on the Empirical Analysis of Brand in Local Enterprises [M]. Jiangsu Fenghuang Science and Technology Press, 2014 (1). (In Chinese)

[3] Simon, Carol J, Sullivan, Mary W. The Measurement and Determinants of Brand Equity: A Financial Approach[M].INFORMS,1993:76-77.

[4] Keller K L. Conceptualizing, measuring and managing customer based brand equity[J]. Journal of Marketing, 1993, 57(1):1-22.

[5] Philip Kotler. Marketing Management[M]. Beijing: China Renmin University Press,2012:265-267.

[6] Xu Jinan. Research on Brand Competitiveness [M]. Economic Management Press, 2005. (In Chinese)

[7] Qiao Jun, Peng Jisheng. Study on the Influencing Factors and Evaluation Model of Core brand Competitiveness - An Empirical Analysis on Local Manufacturing [J]. China Industrial Economics, 2013 (12): 130-142. (In Chinese) 
[8] Bai Yu, Qiao Pengtao. Research on the comprehensive evaluation of brand competitiveness based on analytic hierarchy process [J]. Science \& Technology Progress and Policy, 2005, (12): 140-142. (In Chinese)

[9] Yao Xiaoxiao. Study on how to improve the core competitiveness of China's foreign trade enterprises - Based on Porter's diamond model [J]. Journal of Hubei University of Science, 2015, 35 (1): 46-48. (In Chinese)

[10] Li Hongyu. Study on Core Competitiveness of Small and Medium-sized Foreign Trade Enterprises in China [J]. Market Modernization, 2016 (7): 72-73. (In Chinese)

[11] Wang Xiaodan, Wan Xingya. Quantitative Evaluation and Countermeasure of Core Competitiveness of Small and Medium-sized Foreign Trade Enterprises in China [J]. Taxation and Economy, 2016 (3): 57-62. (In Chinese)

[12] Jiang Wenneng. Ideas and methods for determining the weights of experts in group decision making [J]. Statistics and Decision, 2013 (2): 24-28. (In Chinese) 